\title{
Foreign policy free agents: how lawmakers and coalitions on the political margins help set boundaries for US foreign policy
}

\author{
Patrick Homan ${ }^{1} \cdot$ Jeffrey S. Lantis ${ }^{2}$
}

Accepted: 02 December 2021 / Published online: 22 January 2022

(c) The Author(s), under exclusive licence to Springer Nature Limited 2021

\begin{abstract}
Bipartisan consensus on many US domestic and foreign policy priorities has seemingly collapsed in recent decades, and political parties have become qideologically polarized and divided. While some contend that these dynamics are narrowing the space for congressional foreign policy innovation, we argue that factionalism often fosters creativity in the foreign policy process. Specifically, this article explores the role of 'free agent' progressive Democrats and conservative Republicans in foreign policy decision-making. These members at the ideological extremes of their parties are finding common ground in anti-establishment views and concerns about executive excess, and they are aligning to challenge traditional foreign policy positions. This paper conducts a plausibility probe of a model of congressional foreign policy free agency based upon roll call voting on war powers-related decisions in the Obama and Trump administrations. During both presidencies, our findings suggest that the free agency model has predictive value for foreign policy maneuvering and offers a non-traditional way of thinking about contemporary US foreign policy development.
\end{abstract}

Keywords Foreign policy $\cdot$ Free agents $\cdot$ Ideological extremes $\cdot$ War powers

\footnotetext{
Earlier versions of this paper were presented at the International Studies Association Midwest conference in November 2019, the ISA Annual Meeting in March 2020 (virtually), and the Conference on Domestic Polarization and U.S. Foreign Policy: Ideas, Institutions, and Policy Implications, Sponsored by the University of Heidelberg Center for American Studies and the Department of Political Science, American University, November 12-13, 2020. We greatly appreciate helpful comments from Jordan Tama, Gordon Friedrichs, Lauren Prather, Sibel Oktay, Sarah Hunter, and anonymous reviewers for the journal.
}

Jeffrey S. Lantis

jlantis@wooster.edu

1 Dominican University, River Forest, USA

2 The College of Wooster, Wooster, USA 


\section{Introduction}

Earlier versions of this paper were presented at the International Studies Association Midwest conference in November 2019, the ISA Annual Meeting in March 2020 (virtually), and the Conference on Domestic Polarization and US Foreign Policy: Ideas, Institutions, and Policy Implications, Sponsored by the University of Heidelberg Center for American Studies and the Department of Political Science, American University, November 12-13, 2020. We greatly appreciate helpful comments from Jordan Tama, Gordon Friedrichs, Lauren Prather, Sibel Oktay, Sarah Hunter, and anonymous reviewers for the journal.

In 2020, US officials conducted shuttle diplomacy in the Middle East on the Abraham Accords, a deal to normalize relations between the United Arab Emirates (UAE) and Israel. This made the UAE only the third Arab country to recognize the legitimacy of the Israeli state. President Trump celebrated the accords as a foreign policy success, but it was soon revealed that the UAE had received a powerful incentive to take this step: a highly controversial deal for the sale of \$23 billion worth of advanced weaponry to the UAE, including Reaper drones, F-35 aircraft, and air-to-air missiles. When these details became public in November, just days after the presidential election, members of Congress reacted with alarm. A bipartisan group of lawmakers in the Senate, including Republican Rand Paul (R-KY) and Democrat Chris Murphy (D-CT) immediately introduced legislation to try to stop the deal. Progressive Democrat Representative Ilhan Omar (D-MN) offered corresponding resolutions of disapproval in the House of Representatives, and many members of Congress began to question the 'fine print' of the Abraham Accords.

This case illustrates ways that US politics and foreign policy can be influenced by increasing activism of lawmakers on the ideological 'margins' of traditional parties. For example, the Obama and Trump administrations (2009-2021) saw dramatic increases in polarization and partisanship (Clark et al. 2020; Skocpol and Williamson 2016; Dueck 2018), coupled with rising anti-establishment and populist sentiments. Surveys show that differences between the two parties on fundamental issues like national security and the role of government in society have never been higher. Indeed, partisan identification is more strongly correlated with how individuals approach issues than are factors like race and ethnicity, gender, or level of education (Milligan, October 21, 2019; Pew Research Center, October 5, 2017). The 2020 presidential election illustrated an increase in 'negative partisanship,' with voters more motivated by fear and dislike for the opposite party than by a shared sense of purpose in their own (Abramowitz and Webster 2018; Iyengar and Krupenkin 2018; Klein 2020). Some scholars have taken to describing the two parties as legislative 'teams,' with star players engaged in a political competition (Theriault 2008; Grynaviski 2010).

However, contemporary divisions in politics are actually more multidimensional than sometimes portrayed, and newer tensions appear to be spurring creativity and innovation in the foreign policy process. Even as the major parties drift apart, they are also internally fracturing: Members of political factions on 
both the far-right and far-left ends of the ideological spectrum have become more active as foreign policy entrepreneurs, directly shaping the conduct and effectiveness of US foreign policy (Homan and Lantis 2019, 2019). ${ }^{1}$ In contrast to traditional arguments that ideological polarization simply creates gridlock in American politics (Binder 2014; Thurber and Yoshinaka 2015; Chiou and Rothenberg 2008), this article highlights how a period of fascinating 'free agency' has emerged among members of Congress on the far-left and far-right of the ideological spectrum.

Our theoretical assertion is that lawmakers may perceive significant latitude in the foreign policy process, where free agents resist the gravitational pull of party discipline and median party positions and instead seek out like-minded individuals on the margins in their pursuit of shared objectives (Tama 2019a; 2019b; Harbridge 2015; Curry and Lee 2016). This phenomenon has been well documented in studies of political extremism in Congress, for example Bafumi and Herron (2010) and Minozzi and Volden (2013), as well as studies of factionalism (Homan and Lantis 2019; Lantis and Homan 2019). But less attention has been directed to the implications of these dynamics for individual legislators' behaviors and foreign policy, even as they have gained greater leverage in a closely divided Congress (Koger et al. 2010). The fact that some foreign policy issues are impacted by bipartisan coalitions that include more far-right and far-left lawmakers than moderates also raises important questions about what bipartisanship really means in today's political landscape (see Bryan and Tama 2020, 2020; Thurber and Tama 2018).

To explore this puzzling rise of free agency and its implications for foreign policy, we employ a mixed-method research design to address research questions including: What makes a legislator more likely to be a foreign policy free agent? Why do free agents approach foreign policy issues differently than others within their party? When do they vote like a free agent and agree with those from the other extreme of the political spectrum? Our model of free agency sets out to identify those members of Congress who may be more likely to buck their party on foreign policy matters, including voting with like-minded members from across the aisle-and it advances a new way of assessing the likelihood that lawmakers will be free agents and the impact of their actions. This article probes the plausibility of the model of foreign policy free agency through an analysis of congressional roll call data and selected votes during the Obama and Trump administrations.

\footnotetext{
1 Some free agents may be motivated by a combination of commitments to domestic politics and ideology, along with interests in foreign policy. For example, some may be more isolationist in nature and may be motivated to try to redefine the domestic balance of power between Congress and the executive branch.
} 


\section{A multidimensional model of free agency}

Our model of free agency has several dimensions. First, we argue that foreign policy free agents come from a wide variety of diverse circumstances that might incline them to sometimes turn away from long-standing foreign policy positions and the leadership within their parties (Bendix and MacKay 2017). In other words, free agents have complex motivations and objectives, ranging from a commitment to international causes to isolationism, and from support for interbranch cooperation to rejection of executive excess. Second, today's increased ideological polarization and partisanship may yield greater free agency and foreign policy entrepreneurship by members of Congress who share more ideologically extreme views (Owens 2019; Grofman et al. 2002). While some believe that polarization is a barrier for legislators to work together, we instead suggest that it may help create political 'space' for individual free agents to become empowered in political climates, even where major party organizations might be constrained. Third, we believe that the space created by increased polarization also highlights space or distance between a free agent and the party establishment that allows for their greater involvement in foreign policy.

\section{Personal motivation: diversity, factionalism, and free agency in congress today}

The first dimension of our free agency model recognizes that the power of diverse individual lawmakers and factions is on the rise in foreign policy. While party leaders strive to order the policy process, often serving as effective gatekeepers of the legislative and procedural process (Curry 2015; Gailmard and Jenkins 2007), this does not preclude free agency in foreign policy such as the introduction of bills, voting, issue framing, agenda setting, and building coalitions of support (Lantis 2019; Carter and Scott 2009; Mayhew 2005). Indeed, it may be reasonable to expect that free agency may be increasing in Congress in relation to greater diversity of backgrounds, values, commitments, and experiences that members bring to Capitol Hill. Indeed, the makeup of Congress features more racial, ethnic, gender, and religious diversity than ever before. Many of these players are helping to drive the policy discourse by infusing new energy and ideas (Geiger, January 24, 2019; Burden 2007; Lee 2015, 2009; DiCicco and Fordhamm 2018; Swers 2013; Kriner and Shen 2016; Mansbridge 2003).

Notably, many of these free agents are also members of factions within political parties. They represent ideological subdivisions of major parties that often emerge and organize to pursue particular causes (Lewis 2017; Zariski 1960). Because mass catch-all parties are made up of coalitions with disparate interests (Karol 2009), ideological coalitions have emerged over time in party structures that reflect somewhat coherent groups that shape the policy process (Noel 2016; 2013; Clarke 2017; Roback and James 1978). Factions in modern politics include the New Democrat Coalition, the Republican Study Committee, Blue Dog Democrats, and others (DiSalvo 2010; Yoshinaka 2015). These represent fairly constant tensions in US politics that help shape the development of domestic and foreign policies over time. 


\section{Environmental factors: finding 'space' for policy innovation}

Increasing ideological polarization and partisanship may also yield greater free agency and foreign policy entrepreneurship by members of Congress who share more extreme views. Our approach sees polarization less as an obstacle than an opportunity: We contend that these dynamics may help create political 'space' for lawmakers to become free agents and thus to have more influence during a time of ideological divisions and despite their parties' minority or majority status. Studies of the rise of extremist political views of legislators in Congress (Bonica and Cox 2017; Pinnell 2019), for example, illustrate how lawmakers on the political margins maneuver within and around traditional party constraints to try to achieve their objectives. Similarly, studies of the rise of factionalism in American politics (Luna et al. 2021; Clarke 2017; Blum 2020) anticipated the types of divisions that we have seen emerge in the early years of the Biden administration, where individual free agents and groups used the threat of defection from the party line to negotiate preferred policy outcomes.

Theories of congressional foreign policy advocacy and entrepreneurship greatly inform this approach. Kingdon (2003:21) characterizes an entrepreneur as any 'actor who advocates and seeks to change policy by exploiting opportunities and employing entrepreneurial strategies.' Dissatisfied with establishment policies, they often have unique perspectives as problem-solvers (Marsh and Lantis 2018; Malnes 1995; Mintrom and Norman 2009). Previous research (Lantis and Homan 2019; Rubin 2017; Karol 2009) has also shown that factions can be especially impactful entrepreneurs. They represent ideological subdivisions of major parties-the minorities within the majority and minority parties who demonstrate their own levels of activism and assertiveness. Noel $(2016: 164 ; 2013)$ argues that these are measurable and 'coherent divides' that shape the policy process. 'What splits parties,' he states, 'are rifts between ideologically pure, less compromising members, and more pragmatic, moderate ones' (2016:167). Rubin (2017) also credits the potential utility of party groupings and subgroupings to help 'resolve serious collective action and coordination problems that would otherwise prevent [parties] from effectively challenging congressional leaders for legislative control' (2017:4).

Individual policy-makers and factions within parties appear to have become especially active in the US foreign policy process (Jeong 2018) and bipartisan congressional initiatives and policy changes continue. How is this possible? We argue that broader instability in the party system also seems to help create opportunities for the emergence of outlier voices (free agents), and the influence of nontraditional alliances on the political agenda could be on the rise. As Trubowitz and Harris (2019) argue, a combination of 'hyper-partisanship,' the loss of a central, compelling foreign policy narrative, and the erosion of the public trust are some of the conditions that may be favorable to free agent foreign policy innovation. Members who reside 
Fig. 1 Ideology scores over time (first dimension) (Poole and Rosenthal 2017)

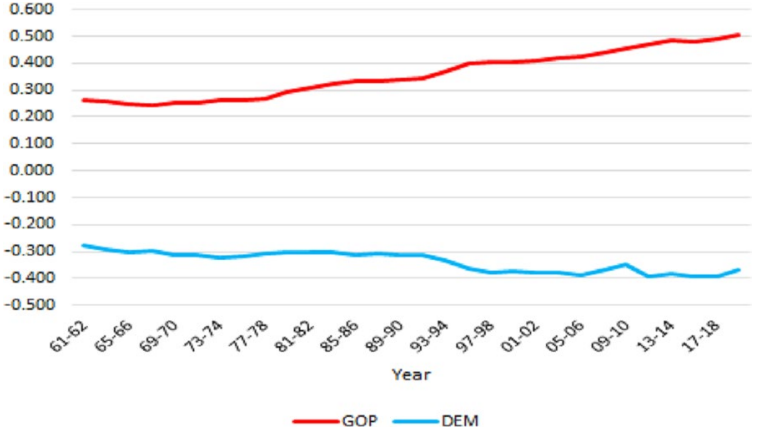

on the ideological margins typically espouse more anti-establishment sentiments and may be less drawn in by centripetal pressures. Indeed, the further from the 'center' or median of the party's political agenda a member is, the more likely these free agents may seek out coalitions of like-minded individuals. Thus, the rise of polarization and fragmentation in American politics (Snyder et al. 2009; Kriner and Shen 2016) has not prevented congressional foreign policy activism and assertiveness. ${ }^{2}$

Finally, anecdotal evidence also suggests that the COVID-19 pandemic of 2019-2021 helped fuel increased free agency by congressional policy entrepreneurs. The political and social landscape was fundamentally disrupted by this public health crisis, threatening party discipline, and leadership leverage. For example, divisions between progressives and moderates in the Democratic Party were laid bare during the presidential election primary race in 2020, and they continued during debates about President Biden's Cabinet selections and top policy agenda items. The absence of regular in-person meetings of the party caucus in Washington, DC, also appeared to create an environment where members sometimes found themselves operating more independently. The very act of whipping votes and building support for establishment positions has been affected by communication issues and physical distance. Campaigning, too, began to adapt to the new era, and some members of Congress found that they had greater latitude to shape their own messages on domestic and foreign policy.

\section{Free agency index}

This study captures ways that individuals on the ideological margins might act as foreign policy free agents by using a new index combining DW-NOMINATE data. ${ }^{3}$ These data and quantitative modeling have been developed by Poole and Rosenthal (2007) to serve as a 'scaling procedure' for representing legislators on a spatial map

\footnotetext{
2 A related, interesting debate has been whether President Trump's seeming free agency might be understood best as cause or effect of extreme polarization (Westwood, Peterson and Lelkes 2019; Kertzer, Brooks, and Brooks, 2021).

3 To our knowledge, there is no comparable measure of how often members of individual political parties on the ideological margins share perspectives or cast votes similar to those of members on the other extreme.
} 
Fig. 2 Anti-establishment scores over time (second dimension) (Poole and Rosenthal 2017)
Fig. 3 Our index of free agency scores over time
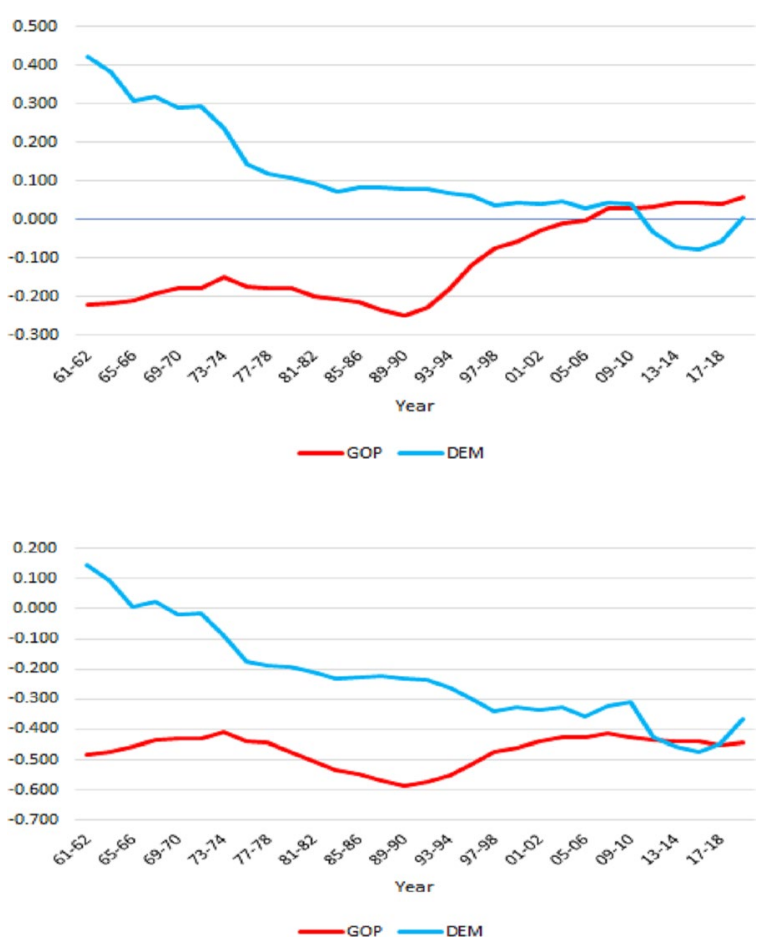

using their voting records. The resulting scores are able to measure how close legislators are across different 'dimensions' that inform congressional voting behavior. The primary DW-NOMINATE score or first dimension measures members of Congress on an ideological scale with liberals on the left (scores closer to -1) and conservatives on the right (scores closer to +1 ) (see Fig. 1). The ideological positions reflected in first-dimension DW-NOMINATE scores have been used extensively across a wide range of studies (McCarty 2016; Caughey and Schickler 2016).

However, because first-dimension scores only capture one aspect of ideological fissures among American political parties today (Enten and Azari 2017), we also include second-dimension DW-NOMINATE scores in our free agency index. Second-dimension DW-NOMINATE scores are seldom used in comparison with the first dimension, as it has historically been viewed as measuring variations within the parties over issues such as currency, nativism, and civil rights, thus primarily capturing regional differences within the parties (e.g., between northern and southern Democrats) (Poole and Rosenthal 2007). More recently, the creators of NOMINATE themselves have begun to argue that the second dimension captures intra-party divisions or insiders versus outsiders cleavages (Poole, Rosenthal, and Hare 2015). Noel (2016) turned this new interpretation into a compromise dimension, arguing that the second dimension captures the degree to which members of congress favor their ideology over the procedural demands of their party. Johnson, McCrary, and Ragusa (2018) also use second-dimension DW-NOMINATE scores to try and capture a populist or establishment vs. anti-establishment divide in the Republican Party. In 
his use of the second dimension to examine partisan warfare, Theriault (2013) found that negative scores seem to indicate members who are more anti-establishment and less willing to compromise. Given this use of second-dimension DW-NOMINATE scores, we include it in our calculation of a free agency index in order to capture the level of anti-establishment sentiment for each legislator (see Fig. 2).

Our free agency index combines the two dimensions of DW-NOMINATE into a multidimensional measure that may help us identify who could serve as a foreign policy free agent and therefore more likely to challenge the status quo or join with someone from the other ideological extreme. By combining first- and second-dimension DW-NOMINATE scores, the resulting index provides a fuller picture of a legislator's potential free agency rather than just focusing on the issue they are rallying around (see Fig. 3). For example, within first-dimension scores, lawmakers that measure closer to the ends of the scale, -1 for liberals and +1 for conservatives, might make someone more likely to be a free agent. We then combine that ideological source of free agency with the willingness of lawmakers to challenge the establishment or act on their own, captured in second-dimension DW-NOMINATE scores. For second-dimension scores, lawmakers that measure a score closer to -1 are more likely to be anti-establishment or independent-minded. The resulting free agent score for each lawmaker populates our index. For the sake of uniformity of scores across the parties, we change the sign of conservative or Republican first-dimension scores from a positive to a negative- therefore lawmakers who are most likely to be free agents for both parties would have scores closer to -2 ( -1 for far-right or left ideology +-1 for anti-establishment).

An historical analysis of first and second DW-NOMINATE data as well as the resulting free agency scores (see Appendix 1) exhibits how our model, and its factors can help explain Congressional foreign policymaking in recent years. Longitudinal congressional data show the wholistic nature of a free agency index as each party has changed in its own way-Republicans becoming much more ideologically polarized (first dimension) and Democrats increasingly anti-establishment (second dimension). Thus, free agency scores allow us to capture the dynamics of both phenomenon and how this is impacting party dynamics and foreign policy debates today.

\section{Methodology}

This paper conducts a plausibility probe of this model of free agency to account for select episodes of US foreign policy development. It employs a mixed-method research design, including statistical analysis of free agency combined with comparative case studies of foreign policy debates. The variables of study for the statistical analysis include the attributes of free agency, and the dependent variable of roll call voting behavior. Case studies selected for this project focus on foreign policy deliberations in both the Democratic and Republican parties during the Obama and Trump administrations. In particular, we examine roll call votes centered around presidential war powers and the use of force (Baum and Potter 2015). Consistent with the logic of the comparative case studies method, as Gerring and Cojocaru (2016:3) argue, the exploration of several in-depth case studies, integrating diverse styles of (observational) evidence, can potentially 'shed light on a broader population, which it represents in an imperfect manner.' 
The cases selected for this study are high-profile instances that received extensive public attention and may be representative of debates over war powers in the past decade. Cases from the first term of the Trump administration (2017-2021) include an exploration of the debate around US support for Saudi Arabia and its war in Yemen and efforts by Congress to prohibit a future war with Iran. The cases from the Obama administration are related to the Libya intervention in 2011 and America's continuing occupation of Afghanistan. ${ }^{4}$ These cases appear to reflect dynamics associated with increased partisanship, including the reinvigoration of far-right and far-left coalitions as well as polarized individual legislators. Furthermore, the cases from these two periods are chosen to exemplify the nuance of free agency coalitions in that they do not always meet previously hypothesized conditions, such as foreign policy issues on the margins or in response to the president or moderate positions. ${ }^{5}$ Case selection criteria are focused on representativeness, offering variation in the research design including different partisan makeups of Congress and variation in extremity of ideological positions (Seawright and Gerring 2008).

As noted above, the data for each case come from Voteview's DW-NOMINATE analysis as well as congressional voting data, bills and motions, and floor debates and speeches. A quantitative analysis will focus on the parties and members of Congress to test the predictive value of the free agency index. Comparing averages across voting blocs (yes v. no) allows to see if free agency is driving different voting patterns among legislators. This examination will also explore data from the free agency index as well as first- and second-dimension DW-NOMINATE scores separately. This will allow for an analysis of how free agency voting patterns are similar or different using the model and its individual components. Is it polarization that is driving votes on war powers legislation or anti-establishment views? Or does the free agency index help explain why those on the extremes are voting together? This analysis of the roll call votes and DW-NOMINATE data will be supplemented by qualitative background of the issues, allowing us to paint a fuller picture of why legislators might be a foreign policy free agent in today's political environment. ${ }^{6}$

\footnotetext{
${ }^{4}$ While the Senate has its own examples of these dynamics, they may be somewhat less pronounced than the House where the bulk of the far-right and far-left members of Congress exist.

5 While these case studies illustrate cases of foreign policy challenge or obstruction, there is a broader universe of possible cases that capture the spirit of innovation.

6 A cursory comparative analysis of a few domestic policy debates from the $116^{\text {th }}$ and 112 th Congress shows the added value of the free agency index for examining foreign policy debates (see Appendix 2). Noticeable differences can be found when comparing the vote data between domestic and foreign policy issues. For instance, when examining Republican voting results, both sessions of Congress show a stronger presence of free agency among foreign policy issues. Furthermore, the results for both parties, especially the Democrats in the 112 th, provide some evidence that foreign policy free agency is not just linked to an increase in second-dimension scores. In fact, the second-dimension among Democrats in the 112th Congress is rather stable across foreign and domestic politics. While this type of comparison does show the more wholistic nature of what free agency captures within foreign policy issues; it should be noted that there is a difference in raw votes across the parties when it comes to domestic issues. In particular, the gravitational pull is different for domestic votes and often leads to larger numbers of free agents. Thus, we are seeing a different dynamic than the free agents at the margins within foreign policy debates and makes a side-by-side comparison difficult.
} 


\section{War powers and free agency during the trump administration}

Congress was deeply polarized during the Trump administration, and these divisions played out even more so in the $116^{\text {th }}$ Congress when Democrats were swept into the House majority. Democrats immediately sought to challenge President Trump's war powers, and they found that some far-right Republicans were willing to join in as well, even though this meant a direct challenge to the White House. There were two issues in particular that led to significant votes in Congress attempting to limit President Trump's war powers. First, in early 2019, lawmakers pushed back on the White House for its long-standing support for Saudi Arabia and its war in Yemen. The Trump administration's unwavering support for Saudi Arabia also came under fire after its lack of a response to the killing of Washington Post columnist, Jamal Khashoggi by Saudi government personnel in October 2018. Second, in January 2020, Congress reacted to a ratcheting up of tensions between the USA and Iran after an exchange of missile attacks on US troops in Iraq and the killing of an Iranian General by American strikes. Members of Congress were upset by the Trump administration's handling of the strikes and thus attempted to reassert their institutional prerogatives on matters of war.

Lawmakers from across the ideological spectrum came together and co-sponsored House Joint Resolution 37 on January 30, 2019, directing the removal of US armed forces from hostilities in Yemen. The primary sponsor of the resolution, Rep. Ro Khanna (D-CA), was the first vice chair of the Congressional Progressive Caucus, and it drew broad support from liberal Democrats. Critically, HJR 37 was also cosponsored by two House Freedom Caucus members, Reps. Kenneth Buck (R-CO) and Andrew Biggs (R-AZ). Aided by the backing of this coalition of lawmakers on both the far-right and far-left, the resolution made its way through the House rather quickly. On February 13, 2019, it passed on a vote of 248-177, with 18 Republicans joining 230 Democrats. Almost all of the Republicans supporting the bill were hardline conservatives from the Freedom Caucus, including its leaders Reps. Jim Jordan (R-OH) and Mark Meadows (R-NC).

Nearly a year later, in early January 2020, members of Congress advanced several different pieces of legislation attempting to contain President Trump and his approach to Iran. First, Democrats in the House introduced a concurrent resolution (H.Con.Res.83) that directed the president, under the War Powers Resolution, to terminate the use of American forces in hostilities in or against Iran. The non-binding resolution was mostly symbolic but sought to limit President Trump's ability to go to war with Iran without first seeking congressional approval. The resolution passed by a vote of 224 to 194, along mostly party lines; however, three far-right Republicans joined Democrats. A few weeks later, Congress again took up legislation surrounding President Trump's war powers. The 'No War Against Iran Act' (H.R. 550) was proposed by a bipartisan group of legislators with a number of goals, including 
prohibiting the use of federal funds for any use of military force against Iran without Congressional authorization. The bill also took aim at appealing the 2002 Authorization for Use of Military Force (AUMF) Against Iraq resolution which had been used by subsequent administrations as justification for a range of actions from targeting ISIS and involvement in the Syrian civil war. Lawmakers from both parties, especially the far-right and far-left, have expressed unease with the use of the AUMF for years. The vote passed 236-166 with 11 Republicans joining the Democratic majority. These war powers votes provide fruitful areas of exploration for foreign policy free agency and how the dynamics of the Trump administration might have impacted lawmakers' behavior.

\section{Free agency in the 116th congress}

Challenges to President Trump's war powers during the $116^{\text {th }}$ Congress were representative of the significant inter-party differences as well as some fragmentation within the major parties. Among the outspoken representatives on the political left in the Progressive Caucus were some of the traditional liberal stalwarts of the House, including Reps. Barbara Lee (D-CA) (with a free agency index score in the 116th Congress of -1.269), Jerrold Nadler (D-NY) (-1.016), Zoe Lofgren (D-CA) (-0.848), and Jackie Speier (D-CA) (-0.837). This group joined with the many new, far-left liberal members of Congress, including Reps. Rashida Tlaib (D-MI) (-1.264), Ilhan Omar (D-MN) (-1.253), Ayanna Pressley (D-MA) (-1.248), and Alexandria Ocasio-Cortez (D-NY) (-1.212). Not surprising, all of these Democrats with the highest free agent scores voted in favor of the three war powers resolutions. Meanwhile, among the House Freedom Caucus members and hardline conservatives who were anti-establishment included Reps. Jordan (-0.943), Meadows (-0.805), Mo Brooks (R-AL) (-1.096), Warren Davidson (R-OH) (-1.037), and Morgan Griffith (R-VA) (-0.987). Many of these lawmakers appeared to rally around the cause of challenging continued US support for Saudi Arabia and the fear of another war in the Middle East, this time with Iran.

Results of an analysis of the three roll call votes discussed above are consistent with our expectations that GOP supporters of war powers resolutions would have a lower free agent score. These voting patterns highlight the importance of foreign free agency. For instance, one of the 'yes' votes for all three pieces of legislation was Rep. Thomas Massie (R-KY), and he had the lowest free agency scores among voting Republicans ${ }^{7}$ at the time -1.413 . Rep. Matthew Gaetz (R-FL) also voted for all three war powers bills and had a free agency score of -1.182 , one of the lowest within the GOP. In fact, some of the Republicans who voted for these resolutions had free agency scores lower than some of the Democrats they voted alongside. Massie and Gaetz were often joined by far-right House Freedom Caucus members such as Reps. Chip Roy (R-TX) (-1.40), Andy Biggs (-1.357), David Schweikert (R-AZ) (-0.926), and Alex Mooney (R-WV) (-0.872), all of whom voted for two of

\footnotetext{
7 Justin Amash (R-MI) had the lowest free agent score at the time for Republicans, but answered 'Present' for this particular vote. Amash would later leave the Republican Party and become an Independent in July 2019.
} 
Table 1 116th House Republican war powers votes and free agency scores

\begin{tabular}{|c|c|c|c|c|c|c|c|}
\hline & \multirow[b]{2}{*}{ ALL GOP (208) } & \multicolumn{2}{|l|}{ HJR 37} & \multicolumn{2}{|l|}{ HR550 } & \multicolumn{2}{|l|}{ HCR 83} \\
\hline & & Yes (18) & No (177) & Yes (11) & No (164) & Yes (3) & No (186) \\
\hline 1st Dim Avg & -.502 & -.626 & -.494 & -.604 & -.498 & -.606 & -.508 \\
\hline 2nd Dim Avg & .059 & -.349 & .119 & -.380 & .103 & -.603 & .088 \\
\hline FA Score Avg & -.443 & -.975 & -.375 & -.984 & -.394 & -1.209 & -.420 \\
\hline
\end{tabular}

Table $2116^{\text {th }}$ House Democrat war powers votes and free agency scores

\begin{tabular}{|c|c|c|c|c|c|c|c|}
\hline & \multirow[b]{2}{*}{ ALL Dems (241) } & \multicolumn{2}{|l|}{ HJR 37} & \multicolumn{2}{|l|}{ HR550 } & \multicolumn{2}{|l|}{ HCR 83} \\
\hline & & Yes (230) & No $(0)$ & Yes (224) & No (2) & Yes (220) & No (8) \\
\hline 1st Dim Avg & -0.369 & -0.370 & - & -0.374 & -0.137 & -0.380 & -0.144 \\
\hline 2nd Dim Avg & 0.005 & -0.001 & - & 0.002 & 0.040 & -0.008 & 0.311 \\
\hline FA Score Avg & -0.364 & -0.371 & - & -0.372 & -0.097 & -0.388 & 0.167 \\
\hline
\end{tabular}

the three bills. These individual lawmakers also exemplify the predictive strength of free agency in that those who voted for these war powers resolutions did not all have the same ideological profile or similar relationship with the GOP establishment: Some were far-right and anti-establishment but others were only moderately conservative or unlikely to buck their party leaders. The free agency index is better able to account for this diversity among individuals. A comparison of the mean scores of all Republicans House members alongside the various voting blocs (see Table 1) for each roll call helps to highlight this predictive value (Table 2).

More broadly, the free agent index scores of Republican supporters of these war powers resolutions appear to provide some explanation for why this unique group came together. For each vote, Republicans who voted yes had dramatically different free agent scores than mean scores for the party as well as those individuals who voted no. Free agents were more ideologically conservative, but they also exhibited differences in their level of anti-establishment feelings, seen in their second-dimension averages. This is especially evident for the few who voted for HCR 83, which included Reps. Gaetz $(-0.556)$, Rooney (-0.518), and Massie (-0.735). In fact, House Minority Leader Kevin McCarthy (R-CA) said he was "very shocked" that Gaetz voted against the president and the GOP leadership (Barbash 2020). This provides evidence that lawmakers' relationship with the party establishment may be just as important, if not more, than their ideological learnings when it comes to certain foreign policy issues.

These cases are especially noteworthy because the resolutions could have passed without any Republicans. This raises an interesting prospect that select issues could 'activate' free agents and encourage their engagement in cross-party coalitions. Legislators on both the far-left and the far-right seem to be more likely to come together on issues of constitutional struggles between the White House and Congress, especially the tug-of-war over war powers. In this instance, though, Trump loyalists like Rep. Gaetz were in a bind, caught in a struggle between party and principle (Schreckinger 2018). Gaetz did his best 
to reassure the White House and the GOP of his loyalty at the time, characterizing his vote as a statement of principle targeted at congressional war powers and not the president. This suggests that even in extreme circumstances, free agents might be willing to create an anti-war coalition both in terms of their ideological views against foreign intervention as well as their constitutional beliefs about war powers residing with Congress. Human rights, media, and popular concerns over the killing of Khashoggi might have also led to a greater willingness to cross the aisle.

In contrast to an analysis of Republican free agents, a survey of Democratic votes does not shed as much light on the free agency phenomenon, since almost the entire party was willing to challenge President Trump's war powers across all three votes studied here. However, a few cases are noteworthy. For instance, the two no votes for HR 550 were cast by Reps. James Cooper (D-TN) and Conor Lamb (D-PA) and their average scores showed significant differences with their party's yes voters and the overall party averages - mostly due to their more moderate ideologies. Cooper was a member of the Blue Dog Coalition, while Lamb was a standard bearer for moderate Democrats, even sparring with progressives like Rep. Alexandria OcasioCortez (D-NY) from time to time. The vote for HCR 83 also provides some interesting results for thinking about free agency among Democrats at the time. The eight Democrats who voted no had both substantially more moderate ideologies as well as more loyalty to the establishment. Rep. Max Rose (D-NY), a combat veteran, was one of the eight who broke from the caucus and voted against the war powers resolution saying that he refused 'to play politics with questions of war and peace' (Parkinson 2020). Rose's free agent score (-0.073) and personal background exhibit the multi-dimensionality of congressional foreign policy today. Furthermore, the small opposition to HCR 83 leads to broader questions about what the 'establishment' among Democrats was at the time: was that to the party itself or to the foreign policy establishment idea of not challenging the president or 'playing politics' on war powers issues? These questions merit further investigation among American political parties today and their members' views on foreign policy debates.

\section{War powers and free agency during the Obama administration}

In 2011, President Obama also faced congressional foreign policy challenges from representatives at opposite ends of the political spectrum, who appeared less likely to follow the guidance of moderate party leaders or support their party's leader in the White House. In particular, President Obama faced newly emboldened Republicans after a large group of far-right conservative 'Tea Party' legislators had just swept to power in the November 2010 midterms as part of a wave of frustration with the White House. Tea Party Republicans had campaigned on the promise to rein in the executive in domestic and foreign affairs, and to reassert congressional power over issues such as military action. At the same time, Obama faced opposition from within his own party, as anti-war voices on the Democratic left had been empowered after years of fighting the Bush administration over its wars in Afghanistan and Iraq. The resulting Progressive-Tea Party free agents would challenge America's continuing occupation 
of Afghanistan as well as the emerging Libya intervention, putting pressure on both the Obama administration and their parties as well.

One of the leading voices in challenging the Obama administration and its war powers was Rep. Dennis Kucinich (D-OH), a longtime leader of the far-left as well as anti-war sentiments in the House. In March of 2011, Kucinich introduced a bipartisan sponsored resolution (H.Con.Res.28) that directed the President, pursuant to the War Powers Resolution, to remove American armed forces from Afghanistan by the end of the year. Kucinich had also made a similar effort in 2010, which failed by a vote of 65-356 with five Republicans joining 60 Democrats. However, this time, in 2011, Kucinich was trying to take advantage of decreasing public support for America's occupation of Afghanistan and possibly the new influx of right-wing Republicans. And while this resolution failed as well, 93-321, the increase in yes votes showed waning congressional support within both parties as eight Republicans voted alongside 85 Democrats.

Undeterred, Kucinich would continue to pressure the Obama White House on war powers issues. In June of 2011, America's intervention in Libya had been underway for nearly three months, and members of Congress from across the political spectrum became increasingly concerned about the scope of US operations. These developments led Kucinich to once again propose a bipartisan concurrent resolution (H.Con.Res.51) that directed the president, pursuant to the War Powers Resolution, to remove the US armed forces from Libya within 15 days after its adoption. Unlike his efforts against America's war in Afghanistan, Kucinich's challenge of the Libya intervention quickly gained traction, including a groundswell of support among Republicans. Lawmakers on both the far-right and left were particularly upset with the Obama administration's failure to provide an explanation to Congress on why it thought it was lawful for the operation in Libya to continue. In fact, the passage of Kucinich's resolution was only avoided in large part because House Speaker John Boehner (R-OH) abruptly postponed the vote for it and then developed a less drastic alternative that siphoned off Republican support.

Boehner's resolution (H.Res.292) did not call for a military withdrawal, but rebuked President Obama for failing to provide a 'compelling rationale' for the Libyan mission, and then demanded answers about the operation within 14 days. By presenting his own rival resolution, Boehner hoped to thread a needle within his party by both chastising Obama and compelling him to report to Congress, while at the same time, not committing the White House to a specific timeline to remove US troops. In the end, Boehner's resolution passed in a 268-145 vote, with 45 Democrats joining 223 Republicans in support, while Kucinich's resolution failed 148-265, with it splitting the parties more evenly-87 Republicans and 61 Democrats in favor. These war power debates during the Obama administration provide avenues for exploring the nature of foreign policy free agency among lawmakers in the $112^{\text {th }}$ Congress.

\section{Free agency in the 112th congress}

There was significant polarization in Congress during the 112th session, though the patterns of divisions differed from those of the 116th session. Members of the 
Table 3 112th House Republicans war powers votes and free agency scores

\begin{tabular}{llllllll}
\hline & \multirow{2}{*}{ ALL GOP (245) } & HCR 51 & \multicolumn{3}{c}{ HCR 28 } & HR 292 \\
\cline { 3 - 8 } & & Yes (87) & No (144) & Yes (8) & No (222) & Yes (223) & No (10) \\
\hline 1st Dim Avg & -.468 & -.542 & -.428 & -.564 & -.462 & -.465 & -.570 \\
2nd Dim Avg & .034 & -.122 & .135 & -.382 & .056 & .056 & -.354 \\
FA Score Avg & -.434 & -.664 & -.293 & -.946 & -.406 & -.409 & -.924 \\
\hline
\end{tabular}

Table 4 112th House Democrats war powers votes and free agency scores

\begin{tabular}{llllllll}
\hline Democrat FA & ALL Dems (200) & HCR 51 & \multicolumn{3}{c}{ HCR 28 } & \multicolumn{3}{c}{ HR 292 } \\
\cline { 2 - 7 } & & Yes (61) & No (121) & Yes (85) & No (99) & Yes (45) & No (135) \\
\hline 1st Dim Avg & -.393 & -.464 & -.363 & -.470 & -.333 & -.306 & -.426 \\
2nd Dim Avg & -.033 & -.161 & .035 & -.195 & .103 & .127 & -.076 \\
FA Score Avg & -.426 & -.625 & -.328 & -.662 & -.231 & -.178 & -.502 \\
\hline
\end{tabular}

Progressive Caucus continue to score high on our free agency index in the 112th session of Congress including Reps. Barbara Lee (D-Ca) (-1.27), Pete Stark (D-WI) $(-1.236)$, and John Conyers Jr. (D-MI) (-1.17). Meanwhile, highly conservative and anti-establishment members of the Republican Party also had free agency scores in line with our initial prediction, including Reps. Justin Amash (R-MI) (-1.411), Joe Walsh (R-IL) (-1.415), and Jeff Flake (R-AZ) (-1.373). Moreover, the lawmakers with the 'strongest' free agency scores were also those most likely to vote for the war powers legislation mentioned above. The differences in free agency scores between those who supported or opposed these war powers resolutions give further evidence to the predictive value of both ideology and anti-establishment in foreign policy debates today.

An analysis of the roll call data for HCR 51 (illustrated in Tables 3 and 4) provides evidence of the predictive power of free agency. Many of the Democrats with the lowest free agent scores were those who ended up voting for the Kucinich bill and against their own president. In fact, the average free agent score for a Democrat who voted yes $(-0.625)$ was substantially lower than the average Democrat who voted no $(-0.328)$ and the entire party caucus $(-0.426)$. In a similar fashion, Republicans who voted for the bill $(-0.664)$ also had significantly lower free agent scores than those who did not $(-0.293)$ and their entire party $(-0.434)$.

These data signify the variety of voices that the Libya debate brought together. Those voting in favor included Tea Party leader Michelle Bachmann (R-MN) $(-0.614)$ as well as Congressional Progressive Caucus Chair Raul Grijalva (D-AZ) $(-0.854)$. In fact, nearly half of those who voted for the bill were members of these far-right and far-left coalitions. The level of Republican backing for the bill led to the Wall Street Journal to brand the supporters 'Kucinich Republicans.' The variety of voices within the GOP yes votes is also noteworthy, as Republican anti-war voices, such as Reps. Walter B. Jones (R-NC) and Ron Paul (R-TX), had significantly different free agent scores $(-0.606$ and -1.368$)$ and particular profiles-Jones being more moderate and less likely to buck the party, and Paul being more conservative and much more anti-establishment. 
These trends for free agency scores also hold up for helping to explain the voting result on HCR 28, with the notable difference being the smaller group of Republicans who voted in support of the resolution. However, the eight Republicans who did vote in favor had a much lower free agency score $(-0.946)$ than those who voted no $(-0.406)$ and the entire GOP $(-0.434)$. In fact, many of these Republicans also voted yes on the Afghanistan war powers resolution including anti-war voices such as Representatives Jones and Paul as well as conservatives like Reps. John Campbell (R-CA) $(-1.163)$ and Jason Chaffetz (R-UT) $(-0.925)$. The same held true for Democrats who voted for HCR 28 , as they had a much lower free agency score $(-0.662)$ than those who voted no $(-0.231)$ and the entire party $(-0.426)$. Free agency scores identified predictable lawmakers that we expected to vote against their president, including Reps. Jerrold Nadler (D-NY) (-1.016), Pete Stark (D-CA) (-1.236), and Barbara Lee $(-1.27)$. However, the data show that it was not always about being ideologically on the far-left compared to the rest of the Democratic party, as it also mattered how much a legislator was willing to go against its party's establishment. This is an important component of this case for Democrats voting against President Obama's war powers.

Finally, an analysis of Boehner's competing bill over war powers in Libya offers an interesting case to examine how well free agency scores held up under a resolution proposed by a more moderate leader. In this instance, free agency among Republicans was really tested with a dilemma between voting with their party but having to do so with a rather watered-down bill on the war in Libya. While some Republicans voted for both, free agents seemed to vote against Boehner's resolution-with a score $(-0.924)$ much lower than the yes votes $(-0.409)$. Of the ten who voted no, many were Tea Party members or from the far-right wing of their party, including Louis Gohmert (R-TX) (-0.955), Tim Huelskamp (R-KS) (-1.21), and Joe Walsh (R-IL) (-1.415). They were ideologically conservative, but also very likely to vote against their party, and it showed in this instance.

Democrats were also put in a tough position over Boehner's resolution, and it split the party up in interesting ways. Like Republicans, those Democrats who voted against H.Res. 292 were more likely to have a free agent profile $(-0.502)$ than those who voted yes $(-0.178)$, but they were close to being on average in comparison with the entire party $(-0.426)$. Many of those Democrats who voted for both of Kucinich's war powers resolutions voted no in this instance, but they were also joined by a group of more moderate or establishment members of their party. Moreover, there were some, like Kucinich himself that supported Boehner's effort despite its moderated tone, but he was also joined by Democrats that would not be typical free agents, and instead who might have been taking advantage of the fact that this vote against the White House came with little actual effect.

\section{Analysis and conclusions}

This study offers evidence that it is possible to identify individual lawmakers on the political left and right that might be more likely to serve as foreign policy free agents, finding common ground with others on the ideological extremes to promote policy innovations and corrections. Given the historical trends within the parties, 
these actors seem especially important in today's narrowly divided Congress, where party leaders may be casting widely for votes. This study suggests that the willingness to forcefully weigh in on foreign policy debates by free agents is due not only to their ideological leanings but also their (often contentious) relationships with the party establishment and its traditional policy agenda. Moreover, there is evidence that the free agency phenomenon is somewhat distinct to foreign policy debates in comparison with domestic policy. Indeed, the coalitions and strategies that are emerging may reflect the development of a 'new normal' on Capitol Hill. This could include even greater intervention by factions and free agents who are committed to particular objectives - a potentially more fluid and unpredictable future, less bound by party structures and traditional commitments.

The case studies explored in this study, as well as today's headlines, demonstrate the impact this phenomenon is having on the conduct and effectiveness of US foreign policy. Free agents periodically challenge their own party leaders and the White House, raising questions about prevailing theories of party discipline (Cox and McCubbins 2005; Jenkins and Monroe 2014; Curry 2015; Gailmard and Jenkins 2007), foreign policy advocacy and entrepreneurship (Lantis 2019; Carter and Scott 2009; Marsh and Lantis 2018), and implications of the 'tribalization' of US politics (Goldberg 2019). We also find that a deeper dive on the motivations of foreign policy free agents may be in order, including the internationalist/isolationist dimension of US foreign policy and willingness to challenge the status quo views of the broader liberal international order. ${ }^{8}$ Additional research is needed, however, including conducting more in-depth quantitative analysis of war powers votes as well as other possible foreign policy free agency issues such as trade or immigration. Future positive results would provide even stronger evidence in support of our model and address case selection issues for broader generalizability about the rise of free agency and their increasing impact on US foreign policy. ${ }^{9}$

\section{Appendix}

See Tables 5, 6

\footnotetext{
${ }^{8}$ A related debate is whether President Trump's foreign policy activism should be understood more as a cause or effect of extreme polarization (Westwood, Peterson and Lelkes 2019).

${ }^{9}$ Domestic cases were selected with the criteria that they were issues that were domestic in nature, which a vote took place in the House of Representatives, touched on a range of topics, consistency across the years, and brought together a bipartisan number of Republican and Democratic voters. The 116th Congress, again, represented a challenge of case selection due to few amount of bills passed during the Trump administration and the number of those that were bipartisan.

112th Legislation: H.R. 1540 National Defense Authorization Act for FY2012, S.365 Budget Control Act of 2011, and H.R. 1249: Leahy-Smith America Invents Act.

116th Legislation: HR 6395 Defense Authorization Act for FY2021, S47 Natural Resources Management Act, and HR 5430 USMCA Implementation Act.
} 
Table 5 Average scores over time

\begin{tabular}{lllllll}
\hline & First dimension & & \multicolumn{2}{c}{ Second dimension } & \multicolumn{2}{c}{ Free agency } \\
\hline & GOP & DEM & GOP & DEM & GOP & DEM \\
$1960 \mathrm{~s}$ & -.252 & -.295 & -.203 & .344 & -.456 & .048 \\
$1970 \mathrm{~s}$ & -.268 & -.311 & -.172 & .180 & -.440 & -.131 \\
$1980 \mathrm{~s}$ & -.328 & -.307 & -.220 & .082 & -.548 & -.225 \\
$1990 \mathrm{~s}$ & -.384 & -.351 & -.132 & .058 & -.516 & -.293 \\
$2000 \mathrm{~s}$ & -.429 & -.371 & .004 & .041 & -.425 & -.331 \\
$2010 \mathrm{~s}$ & -.485 & -.387 & .044 & -.046 & -.441 & -.433 \\
\hline
\end{tabular}

Table 6 Domestic case votes from 112 and 116th congress

112 th House republican domestic votes \& free agency scores

\begin{tabular}{|c|c|c|c|c|c|c|c|}
\hline & \multirow[b]{2}{*}{ ALL GOP (245) } & \multicolumn{2}{|l|}{ HR 1540} & \multicolumn{2}{|l|}{ S 365} & \multicolumn{2}{|l|}{ HR 1249} \\
\hline & & Yes (190) & No (43) & Yes (174) & No (66) & Yes (168) & No (67) \\
\hline 1st Dim Avg & -.468 & -.438 & -.597 & -.427 & -.580 & -.446 & -.529 \\
\hline 2nd Dim Avg & .034 & .105 & -.238 & .070 & -.051 & .072 & -.066 \\
\hline FA Score Avg & -.434 & -.332 & -.835 & -.358 & -.631 & -.374 & -.595 \\
\hline
\end{tabular}

112 th house democrats domestic votes \& free agency scores

\begin{tabular}{|c|c|c|c|c|c|c|c|}
\hline \multirow[t]{2}{*}{ Democrat FA } & \multirow[b]{2}{*}{ ALL Dems (200) } & \multicolumn{2}{|l|}{ HR 1540} & \multicolumn{2}{|l|}{ S 365} & \multicolumn{2}{|l|}{ HR 1249} \\
\hline & & Yes (93) & No (93) & Yes (95) & No (95) & Yes (136) & No $(50)$ \\
\hline 1st Dim Avg & -.393 & -.323 & -.466 & -.335 & -.452 & -.375 & -.456 \\
\hline 2nd Dim Avg & -.033 & .126 & -.194 & .082 & -.148 & .012 & -.136 \\
\hline FA Score Avg & -.426 & -.197 & -660 & -.253 & -.600 & -.363 & -.592 \\
\hline
\end{tabular}

116 th House republican votes \& free agency scores

\begin{tabular}{llllll}
\hline & ALL GOP (202) & HR 6395 & S 47 & & \\
& & Yes (108) & No (81) & Yes (133) & No (62) \\
\hline 1st Dim Avg & -502 & -432 & -.595 & -.459 & -.614 \\
2nd Dim Avg & .059 & .167 & -.037 & .128 & -.044 \\
FA Score Avg & -.443 & -.265 & -.632 & -.331 & -.658 \\
\hline
\end{tabular}

116th House democratic votes \& free agency scores

\begin{tabular}{llllll}
\hline & ALL Dems (241) & HR 6395 & HR 5430 & & \\
& & Yes (187) & No (43) & Yes (193) & No (38) \\
\hline 1st Dim Avg & -369 & -347 & -463 & -353 & -446 \\
2nd Dim Avg & .005 & .074 & -307 & .057 & -243 \\
FA Score Avg & -364 & -273 & -770 & -296 & -689 \\
\hline
\end{tabular}




\section{References}

Abramowitz, A.I., and S.W. Webster. 2018. Negative partisanship: Why Americans dislike parties but behave like rabid partisans. Advances in Political Psychology 39 (1): 119-135.

Bafumi, J., and M.C. Herron. 2010. Leapfrog Representation and extremism: A study of American voters and their members in congress. American Political Science Review 104 (3): 519-542.

Barbash, F. 2020. Matt Gaetz, the 'Trumpiset Congressman,' Cites Principles for Bucking President on War Powers. Kevin McCarthy is 'Very Shocked'. Washington Post January 10 https://www.washi ngtonpost.com/nation/2020/01/10/gaetz-war-powers/

Baum, M.A., and P.B.K. Potter. 2015. War and democratic constraint: How the public influences foreign policy. Princeton, NJ: Princeton University Press.

Bendix, W., and J. MacKay. 2017. Partisan infighting among house republicans: Leaders, factions, and networks of interests. Legislative Studies Quarterly 42 (4): 549-577.

Binder, S.A. 2014. Polarized we govern? Washington, DC: Brookings Inst. Press.

Binder, S.A. 2003. Stalemate: Causes and consequences of legislative gridlock. Washington, DC: Brookings Institution Press.

Blum, R.M. 2020. How the tea party captured the GOP: Insurgent factions in american politics. Chicago, IL: University of Chicago Press.

Bonica, A., Gary W. C. 2017. Ideological extremists in the US Congress: Out of Step but Still in Office. SSRN 2970341.

Bryan, J., Jordan T. 2020. The prevalence of bipartisanship in U.S. Foreign Policy: An Analysis of Important Congressional Votes. Prepared for presentation at workshop, Domestic Polarization and U.S. Foreign Policy: Ideas, Institutions, and Policy Implications. Heidelberg University. November.

Burden, B.C. 2007. Personal roots of representation. Princeton: Princeton University Press.

Carter, R.G., and J.M. Scott. 2009. Choosing to lead: Understanding congressional foreign policy entrepreneurs. Durham, NC: Duke University Press. Carter.

Carter, R.G., and J.M. Scott. 2010. Understanding congressional foreign policy innovators: Mapping entrepreneurs and their strategies. The Social Science Journal 47 (2): 418-438.

Carter, Rh G., James M. S. 2013. Hitting the reset button: Why is cooperation So Hard? In Ralph G. Carter (Ed.), Contemporary Cases in U.S. Foreign Policy: From Terrorism to Trade (pp. 167-199). Washington, DC: CQ Press.

Carter, R. G., James M. S. 2017. Choosing to Lead in a shrinking space: partisanship, polarization, and congressional foreign policy entrepreneurship. Paper presented to the Annual Meeting of the International Studies Association.

Carter, R.G., M.S. James, and R. Charles. 2004. Setting a course: Congressional foreign policy entrepreneurs in Post-World War II U S foreign policy. International Studies Perspectives 5 (3): 278-299.

Caughey, D., and E. Schickler. 2016. Substance and change in congressional ideology: NOMINATE and its alternatives. Studies in American Political Development 30 (2): 128-146.

Chiou, F.-Y., and L.S. Rothenberg. 2008. Comparing legislators and legislatures: The dynamics of legislative gridlock reconsidered. Political Analysis 16 (2): 197-212.

Clark, A., F. Justwan, J.E. Carlisle, and M. Clark. 2020. Polarization politics and hopes for a green agenda in the United States. Environmental Politics 29 (4): 719-745.

Clarke, A. J. 2017. The house freedom caucus: Extreme faction influence in the U.S. congress. [PDF file]. Retrieved from http://www.democratic-anxieties.eu/wordpress/wp-content/uploads/2017/10/ Clarke_Berlin2017.pdf.

Cox, G.W., and M.D. McCubbins. 2005. Setting the agenda: Responsible party government in the US house of representatives. Cambridge: Cambridge University Press.

Curry, J. M. 2015. Legislating in the Dark: Information and Power in the House of Representatives. University of Chicago Press.

Curry, J. M., Frances L. 2016. Congress is far more bipartisan than headlines suggest. Washington Post, Monkey Cage Blog, December 20. https://www.washingtonpost.com/news/monkey-cage/wp/2016/ 12/20/congress-is-far-more-bipartisan-than-headlines-suggest/.

Delli Carpini, M.X., and S. Keeter. 1996. What Americans know about politics and why It matters. New Haven, CT: Yale University Press.

De Vries, C., and S. Hobolt. 2012. When dimensions collide: The electoral success of issue entrepreneurs. European Union Politics 13 (2): 264-268. 
DiCicco, J.M., and B.O. Fordham. 2018. The things they carried: Generational effects of the Vietnam war on elite opinion. International Studies Quarterly 62 (1): 131-143.

DiSalvo, D. 2010. The politics of a party faction: The liberal-labor alliance in the democratic party, 1948-1972. The Journal of Policy History 22 (3): 269-299.

Dodd, L.C., and S. Schraufnagel. 2009. Re-thinking legislative productivity: Commemorative legislation and policy gridlock. Congress \& the Presidency 36 (2): 132-147.

Dodd, L.C., and St. Schraufnagel. 2012. Congress and the polarity paradox: Party polarization, member incivility, and enactment of landmark legislation, 1891-1994. Congress \& the Presidency 39 (2): $109-132$.

Dueck, C., 2018. Policy roundtable: The future of conservative foreign policy. Texas National Security Review 30.

Enten, H., Julia A. 2017. The two cracks in the republican party. FiveThirtyEight. March 26. https://fivet hirtyeight.com/features/the-two-cracks-in-the-republican-party/.

Gailmard, S., and J.A. Jenkins. 2007. Negative agenda control in the senate and house: Fingerprints of majority party power. Journal of Politics 3: 689-700.

Geiger, A.W. 2019. In 116th Congress, At Least 13\% of Lawmakers are Immigrants or the Children of Immigrants. Pew Research Center. 24 January. https:/www.pewresearch.org/fact-tank/2019/01/24/ in-116th-congress-at-least-13-of-lawmakers-are-immigrants-or-the-children-of-immigrants/

Gerring, J., and L. Cojocaru. 2016. Selecting cases for intensive analysis: A diversity of goals and methods. Sociological Methods \& Research 3: 392-423.

Goldberg, J. 2019. A nation coming apart: the meaning of the american idea in 2019. The Atlantic. December. www.theatlantic.com/magazine/archive/2019/12/a-nation-coming-apart/600730.

Goldgeier, J. 2019. Is there a new foreign policy consensus forming? War on the Rocks. February 1. https://warontherocks.com/2019/02/assessing-the-texas-national-security-reviews-progressive-andconservative-foreign-policy-roundtables-is-there-a-new-consensus-forming/

Goldman, L. 1990. Qualitative assessment. The Counseling Psychologist 18 (2): 205-213.

Gries, P.H. 2014. The politics of american foreign policy: how ideology divides liberals and conservatives over foreign affairs. Stanford, CA: Stanford University Press.

Grofman, B., W. Koetzle, and A. J. McGann. 2002. Congressional leadership 1965-96: A new look at the extremism versus centrality debate. Legislative Studies Quarterly 27 (1): 87-105

Grynaviski, J.D. 2010. Partisan bonds: political reputations and legislative accountability. New York: Cambridge University Press.

Harbridge, L. 2015. Is bipartisanship dead?: Policy agreement and agenda-setting in the house of representatives. Cambridge: Cambridge University Press.

Homan, P., Jeffrey S. L. 2019. The battle for U.S. foreign policy: Congress, parties, and factions in the 21st century. Palgrave Macmillan Publishers.

Hurlburt, H., Chayenne P. 2016. Can transpartisan coalitions overcome polarization: Lessons from four case studies. Washington, DC: New America. Newamerica.org.final_transpartisan.com.

Iyengar, S., and M. Krupenkin. 2018. Partisanship as social identity; Implications for the study of party polarization. The Forum 16 (1): 23-45.

Jenkins, J.A., and W.M. Nathan. 2014. Negative agenda control and the conservative coalition in the U. S. house. The Journal of Politics 76 (4): 1116-1127.

Jeong, G.-H. 2018. Measuring foreign policy positions of members of the US congress. Political Science Research Methods 6 (1): 181-196.

Johnson, L.R., D. McCray, and J.M. Ragusa. 2018. \#NeverTrump: Why republican members of congress refused to support their party's nominee in the 2016 presidential election. Research and Politics 5 (1): $1-10$.

Karol, David. 2009. Party position change in american politics: coalition management. Cambridge: Cambridge University Press.

Kertzer, J. D., Stephen G. B., Deborah J. B. 2021. Do partisan types stop at the water's edge? Forthcoming in Journal of Politics.

Kingdon, J.W. 2003. Agendas, alternatives, and public policy. New York: Longman.

Klein, E. 2020. Why We're polarized. New York: Simon and Schuster.

Koger, G., S. Masket, and H. Noel. 2010. Cooperative party factions in american politics. American Politics Research 38 (1): 33-53.

Kriner, D.L., and F.X. Shen. 2016. Conscription, inequality, and partisan support for war. Journal of Conflict Resolution 60 (8): 1419-1445. 
Kupchan, C.A., and P.L. Trubowitz. 2007. Grand strategy for a divided America. Foreign Affairs 4: 71-83.

Lantis, J. S. 2019. Foreign policy advocacy and entrepreneurship: How a new generation in congress is shaping U.S. engagement with the World. Ann Arbor, MI: University of Michigan Press.

Lantis, J.S., and P. Homan. 2019. Factionalism and US foreign policy: A social psychological model of minority influence. Foreign Policy Analysis 15 (2): 157-175.

Lee, F.E. 2015. How party polarization affects governance. Annual Review of Political Science 15 (3): 261-282.

Lee, F.E. 2009. Beyond ideology: Politics, principles, and partisanship in the US senate. Chicago: University of Chicago Press.

Levendusky, M.S. 2018. Americans, Not partisans: Can priming American national identity reduce affective polarization? The Journal of Politics 80 (1): 59-70.

Lewis, V. 2017. The president and the parties' ideologies: Party ideas about foreign policy since 1900. Presidential Studies Quarterly 47 (1): 27-61.

Luna, J.P., R.P. Rodríguez, F. Rosenblatt, and G. Vommaro. 2021. Political parties, diminished subtypes, and democracy. Party Politics 27 (2): 294-307.

Lupton, D.L. 2017. Out of the service: into the house: military experience and congressional war oversight. Political Research Quarterly 70 (2): 327-339.

Malnes, R. 1995. 'Leader' and 'Entrepreneur' in international negotiations: A conceptual analysis. European Journal of International Relations 1 (1): 87-112.

Mansbridge, J. 2003. Rethinking representation. American Political Science Review 51 (4): 515-528.

Marsh, K., and J.S. Lantis. 2018. Are all foreign policy innovators created equal? The new generation of congressional foreign policy entrepreneurship. Foreign Policy Analysis 14 (2): 212-234.

Mason, L. 2018. Uncivil agreement: How politics became our identity. Chicago: University of Chicago Press.

Mayhew, D.R. 2005. Divided we govern: party control, lawmaking, and investigations, 1946-2002. New Haven: Yale University Press.

McCarty, N. 2016. In defense of DW-nominate. Studies in American Political Development 30 (2): $172-184$.

Meijers, M.J. 2017. Contagious euroscepticism: The impact of Eurosceptic support on mainstream party position on European integration. Party Politics 23 (3): 413-423.

Milligan, S. 2019. Democrats, republicans, and the New Politics of Hate. US News and World Report 21 October. https://www.usnews.com/news/elections/articles/2019-10-21/democrats-republicans-andthe-new-politics-of-hate.

Minozzi, W., and C. Volden. 2013. Who heeds the call of the party in congress? The Journal of Politics 75 (3): 787-802.

Mintrom, M., and P. Norman. 2009. Policy entrepreneurship and policy change. Policy Studies Journal 4: 649-667.

Noel, H. 2016. Ideological factions in the republican and democratic parties. Annals AAPSS 667.

Noel, H. 2013. Political ideologies and political parties in america. New York: Cambridge University Press.

Owens, J. E. 2019. Congress after the 'Revolution': The continuing problems of governance in a partisan Era. In: American Politics: 2000 and Beyond, pp. 29-63. London: Routledge.

Parkinson, J. 2020. House democrats pass measure limiting Trump's War Powers Against Iran. ABC News January 9. https://abcnews.go.com/Politics/speaker-pelosi-dismisses-foolish-critics-iran-warpowers/story?id=68169227

Pew Research Center. 2017. Key takeaways on american's growing partisan divide over political values. Pew research 5 October https:/www.pewresearch.org/fact-tank/2017/10/05/takeaways-on-ameri cans-growing-partisan-divide-over-political-values/.

Pinnell, N. E. 2019. Minority advantage?: An exploration of minority party status as a benefit for ideological extremists. Ph.D. Dissertation. The University of North Carolina at Chapel Hill.

Poole, K.T., and H. Rosenthal. 2007. Ideology and congress. London: Transaction Publishers.

Poole, K. T., Howard R., Christopher H. 2015. House: Vote on clean DHS funding bill. Voteview Blog.

Poole, K.T., and H. Rosenthal. 2017. Ideology \& congress: A political economic history of roll call voting. New York: Routledge.

Roback, T. H., Judson L. J. 1978. Party factions in the United States. In Frank P. Belloni and Dennis C. Beller (Eds.), Faction politics: political parties and factionalism in comparative perspective. Santa Barbara: ABC Clio. 329-355. 
Rubin, R. B. 2017. Building the bloc: Intraparty organization in the U.S. congress. New York: Cambridge University Press.

Schreckinger, B. 2018. Matt Gaetz is the Trumpiest congressman in Trump's Washington. GQ April 11 https://www.gq.com/story/matt-gaetz-trumpiest-congressman-in-washington.

Seawright, J., and J. Gerring. 2008. Case-selection techniques in case study research: A menu of qualitative and quantitative options. Political Research Quarterly 61 (3): 294-308.

Skocpol, T., and V. Williamson. 2016. The tea party and the remaking of republican conservatism. Oxford University Press.

Snyder, J., R.Y. Shapiro, and Y. Bloch-Elkon. 2009. Free hand abroad, Divide and rule at home. World Politics 61 (1): 155-187.

Stonecash, J.M., M.D. Brewer, and M.D. Mariani. 2003. Diverging parties: social change, realignment, and party polarization. New York: Routledge.

Swers, M.L. 2013. Women in the club: Gender and Policy Making in the Senate. University of Chicago Press.

Szöcsik, E., and A. Polykova. 2019. Euroscepticism and the electoral success of the far right: The role of strategic interaction between center and far right. European Political Science 18 (4): 400-420.

Tama, Jordan. 2020. Forcing the president's hand: How the US congress shapes foreign policy through sanctions legislation. Foreign Policy Analysis 16 (3): 397-416.

Tama, J. 2019a. Anti-presidential bipartisanship in U.S. Foreign policy Under Trump: The Case of the International Affairs Budget. 1 March. Available at SSRN: https://ssrn.com/abstract=33931 70 or https://doi.org/10.2139/ssrn.3393170.

Tama, J. 2019b. Forcing the president's hand: How the US congress shapes foreign policy through sanctions legislation. Foreign Policy Analysis. https://doi.org/10.1093/fpa/orz018.

Tama, J. 2018. The multiple forms of bipartisanship: political alignments in US foreign policy. Social Science Research Council's Democracy Papers series.

Tama, J. 2017. So congress is challenging the president about sanctions? That Has a Long History. Washington Post, Monkey Cage Blog, 16 June. https://www.washingtonpost.com/news/monkey-cage/ wp/2017/06/16/so-congress-is-challenging-the-president-about-sanctions-that-has-a-long-history/.

Theriault, S.M. 2013. The Gingrich senators: The roots of partisan warfare in congress. New York: Oxford University Press.

Theriault, Sean M. 2008. Party polarization in congress. Cambridge: Cambridge University Press.

Thurber, J., and A. Yoshinaka. 2015. American Gridlock: The Sources, Character, and Impact of Political Polarization. Cambridge: Cambridge University Press.

Thurber, J., and J. Tama. 2018. Rivals for power: presidential-congressional relations, 6th ed. Boulder, CO: Rowman \& Littlefield.

Trubowitz, P., and P. Harris. 2019. The end of the american century? Slow erosion of the domestic sources of usable power. International Affairs 95 (3): 619-639.

Vasilopoulou, S. 2018. The radical right and euroskepticism. In J. Rydgren, ed., The Oxford Handbook of the Radical Right. Oxford University Press.

Westwood, S.J., E. Peterson, and Y. Lelkes. 2019. Are there still limits on partisan prejudice? Public Opinion Quarterly 83 (3): 584-597.

Whitefield, S., and R. Rohrschneider. 2015. The salience of European integration to party competition: western and eastern Europe compared. East European Politics and Societies and Cultures 29 (1): 12-39.

Williams, C., and J. Ishiyama. 2018. Responding to the left: The effect of far-left parties on mainstream party euroskepticism. Journal of Elections, Public Opinion and Parties 28 (4): 443-466.

Yoshinaka, A. 2015. Crossing the aisle: Party switching by U.S. Legislators in the Postwar Era. New York: Cambridge University Press.

Zariski, R. 1960. Party factions and comparative politics: Some preliminary observations. Midwest Journal of Political Science 4 (1): 27-51.

Publisher's Note Springer Nature remains neutral with regard to jurisdictional claims in published maps and institutional affiliations. 